\title{
KOMPARASI REKSADANA SAHAM PERUSAHAAN INVESTASI NASIONAL DAN ASING DI INDONESIA DILIHAT DARI KINERJA, MARKET TIMING DAN STOCK SELECTION
}

\author{
Anak Agung Ayu Putri Utami ${ }^{1}$ \\ Luh Gede Sri Artini ${ }^{2}$ \\ ${ }^{1,2}$ Fakultas Ekonomi dan Bisnis Universitas Udayana, Bali, Indonesia \\ e-mail:ptrutami@gmail.com
}

\begin{abstract}
ABSTRAK
Tujuan dari penelitian ini adalah untuk mengetahui signifikansi perbedaan antara reksadana saham perusahaan investasi nasional dan asing di Indonesia dilihat dari kinerja,untuk mengetahui mana yang lebih baik antara reksadana saham perusahaan investasi nasional dan asing dilihat dari market timing dan stock selection. Populasi penelitian ini adalah reksadana saham yang terdaftar pada website Otoritas Jasa Keuangan yang memiliki kinerja outperform selama periode 2014-2016. Pemilihan sampel dilakukan secara obyektif berdasarkan perusahaan investasi. Hasil penelitian menunjukkan bahwa tidak terdapat perbedaan yang signifikan antara reksadana saham perusahaan investasi nasional dan asing di Indonesia dilihat dari kinerja dengan menggunakan Indeks Sharpe, market timing reksadana saham perusahaan investasi nasional lebih baik daripada market timing reksadana saham perusahaan investasi asing dan stock selection reksadana saham perusahaan investasi nasional lebih baik daripada stock selection reksadana saham perusahaan investasi asing.
\end{abstract}

Kata kunci: Reksadana Saham, Kinerja, Market Timing, Stock Selection, Perusahaan Investasi Nasional, Perusahaan Investasi Asing.

\section{ABSTRACT}

The purpose of this research is to know the significance of the difference between a mutual fund company's stock of foreign and national investment in Indonesia viewed from performance,to find out which is better between mutual fund investment company national and foreign views of market timing and stock selection.The population of this research is the mutual fund shares that are listed on the website of the financial services authority-performance outperform during periods of 2014-2016. The selection of the samples was done objectively based on investment companies. Assessment of the performance of mutual fund shares using the Sharpe Index while market timing and stock selection using Treynor Mazuy. The method used is the technique of data analysis in the form of two different test averages with the help of IBM SPSS program.The results showed that there was no significant difference between the mutual fund company's stock of foreign and national investment in Indonesia viewed from the performance by using Sharpe Index, market timing stock mutual fund national invesment better than market timing foreign companies and stock selection mutual fund national invesment better than stock selection foreign companies.

Key words: Mutual Fund, Performance, Market Timing, Stock Selection, National Investment Company, Foreign Investment Company. 


\section{PENDAHULUAN}

Reksadana merupakan salah satu alternatif berinvestasi bagi pemodal atau investor yang memiliki dana terbatas, tidak memiliki waktu dan keahlian untuk menghitung risiko dan return atas investasi yang ditanamkan (Husain dan Dhanraj Sharma, 2014). Hal yang membedakan reksadana dengan instrumen lainnya adalah adanya Manajer Investasi yaitu pihak profesional yang bertugas mengelola dana investasi dari investor reksadana (Baskara, 2015). Kelebihan dan kemudahan yang ditawarkan oleh reksadana membuat instrumen ini dijadikan pilihan yang menjanjikan oleh para investor. Reksadana merupakan instrumen investasi yang dikelola oleh Manajer Investasi sehingga investor memiliki informasi produk reksadana yang valid dari pihak Manajer Investasi tersebut (Kalpesh dan Mahesh, 2012).

Berdasarkan data OJK (Otoritas Jasa Keuangan) untuk tahun 2016, komposisi reksadana yang paling besar dipegang oleh Reksadana Saham yakni sebesar $38,46 \%$ dan yang terendah adalah Reksadana Syariah Pasar Uang sebesar $0,34 \%$. Hal tersebut membuktikan bahwa masyarakat sudah mulai mengenal produk Reksadana dan responnya cukup baik. Manajer Investasi berlomba-lomba untuk memberikan tingkat pengembalian yang cukup menarik melalui strategi investasi yang digunakan agar dapat memberikan keuntungan dan mendapatkan kepercayaan dari para calon investor maupun investornya (Nurjanah, 2016). 
Rudiyanto (2016) menjelaskan ada empat jenis reksadana berdasarkan kategori instrumen investasinya, yaitu reksadana pasar uang, reksadana pendapatan tetap, reksadana campuran, dan reksadana saham. Keempat jenis reksadana tersebut mempunyai karakteristik tingkat keuntungan dan risiko berbeda-beda sesuai prospektus yang ditawarkan oleh masing-masing reksadana. Komposisi reksadana pada tahun 2013 dan tahun 2014 ditunjukkan pada Gambar 1. dan Gambar 2. dimana reksadana saham lebih diminati oleh investor dibandingkan dengan jenis reksadana yang lain sebagai berikut:

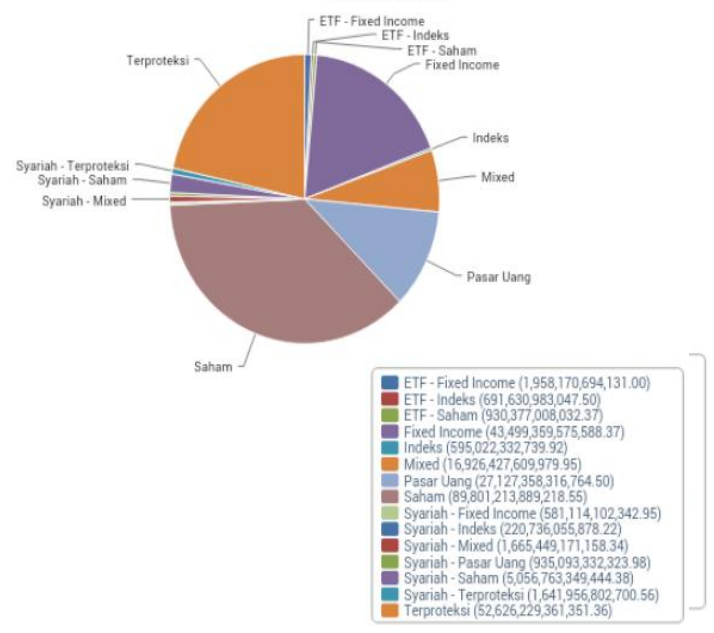

Gambar 1. Komposisi Reksadana Tahun 2013

Sumber: www.ojk.go.id

Gambar 1. menunjukkan bahwa komposisi tertinggi terdapat pada reksadana saham sebesar $\mathrm{Rp}$ 89.801.213.889.218,55 dan kemudian disusul oleh reksadana pendapatan tetap sebesar Rp 43.499.359.575.588,37 lalu reksadana pasar uang sebesar Rp 27.127.358.316.764,50 dan yang paling terendah adalah dari reksa dana campuran sebesar $\mathrm{Rp}$ 16.926.427.609.979,95. 


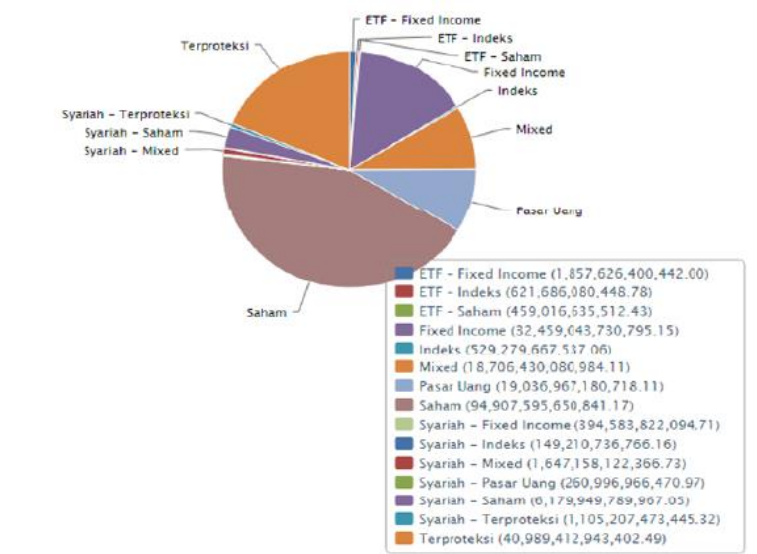

Gambar 2. Komposisi Reksadana Tahun 2014

Sumber: www.ojk.go.id

Gambar 2. menunjukkan bahwa komposisi tertinggi terdapat pada reksadana saham sebesar Rp 94.907.595.650.841,17 dan kemudian disusul oleh reksadana pendapatan tetap sebesar Rp 32.459.043.730.795,15 lalu reksadana pasar uang sebesar Rp 19.036.967.180.718,11 dan yang paling terendah adalah dari reksa dana campuran sebesar $\mathrm{Rp}$ 18.706.430.080.984,11.

Narend (2014) menyebutkan reksadana saham merupakan jenis reksadana dengan potensi keuntungan paling tinggi dan mempunyai risiko yang lebih tinggi dibanding reksadana jenis lain. Meskipun memiliki risiko tinggi, investor lebih tertarik melihat potensi keuntungan yang mampu dihasilkan oleh reksadana saham (Hanggoro, 2014). Reksadana saham menanamkan dana yang dikelolanya sekurang-kurangnya $80 \%$ berbentuk saham atau ekuitas yang mempunyai risiko tinggi.

Penilaian kinerja reksadana saham sangat perlu diperhatikan oleh para investor agar dapat memilih dan membandingkan reksadana saham 
yang mampu memberikan keuntungan yang optimal selain itu, penilaian kinerja diperlukan karena tidak hanya melihat dari return yang dihasilkan tetapi juga mempertimbangkan risiko dari suatu reksadana saham. Shilpi Pal (2014) menyatakan metode yang dipergunakan untuk mengukur kinerja reksadana saham salah satunya adalah Sharpe.

Penggunaan Indeks Sharpe didasarkan kepada alasan pengukuran risiko yang mempergunakan risiko total sebagai penjumlahan dari systemic risk dan unsystemic risk selain itu penggunaan Indeks Sharpe dapat diterapkan untuk semua reksadana karena metode Sharpe tidak memerlukan kinerja benchmark dalam pengukuran risikonya (Gopalakrishnan, 2014). Hasil kinerja reksadana saham tersebut kemudian akan dibandingkan dengan kinerja IHSG sebagai benchmark untuk menentukan reksadana saham yang masuk ke dalam kategori outperform dan underperform (Bernadiaz, 2015).

Kemampuan perusahaan investasi dalam mengelola reksadana sahamnya selain dilihat dari kinerjanya dapat juga dilihat dari dua komponen utama yaitu market timing dan stock selection (Fama, 1972). Market timing terkait dengan sejauh mana kemampuan perusahaan investasi dalam memanfaatkan waktu pasar, yaitu kapan saatnya membeli efek dan kapan saat menjualnya kembali (Sung Sin Kim, 2013) sedangkan stock selection terkait dengan kemampuan perusahaan pengelola investasi dalam hal ini manajer investasinya untuk memilih saham - saham yang tepat untuk dimasukkan atau dikeluarkan dari portofolio reksadana 
sehingga memberikan tingkat pengembalian (return) yang lebih baik dari tingkat pengembalian pasar serta meningkatkan kinerja reksadana saham itu sendiri (Keith dan Dirk, 2012). Penggunaan market timing dan stock selection didasarkan pada alasan periode waktu dan kondisi pasar yang berubah sehingga selama mengelola reksadana saham setiap manajer investasi akan melakukan langkah - langkah tersebut untuk mendapatkan tingkat pengembalian yang optimal bagi investor (Benny, 2015).

Penelitian yang dilakukan Winingrum (2011) dalam Dwi Mas (2013) tentang analisis stock selection skills, market timing ability, size reksadana, umur reksadana dan expense ratio terhadap kinerja reksadana saham yang terdaftar di Bursa Efek Indonesia periode tahun 2006-2010 menunjukkan secara parsial bahwa stock selection skill dan market ability berpengaruh signifikan terhadap kinerja reksadana saham sedangkan size reksadana, umur reksadana dan rasio biaya berpengaruh tidak signifikan terhadap kinerja reksadana saham.

Namun penelitian yang dilakukan oleh Deasy (2013) memiliki hasil yang berbeda tentang analisis kemampuan stock selection dan market timing pada reksadana saham di Indonesia periode Januari 2008 - Juli 2013 menunjukkan bahwa stock selection tidak berpengaruh signifikan terhadap kinerja reksadana saham sedangkan market timing berpengaruh signifikan terhadap kinerja reksadana saham. Beberapa hasil penelitian tentang kinerja reksadana, market timing dan stock selection memberikan 
hasil yang berbeda-beda, oleh karena itu perlu dilakukan penelitian lebih lanjut mengenai kinerja reksadana, market timing dan stock selection.

Investor harus memilih perusahaan investasi reksadana saham yang memiliki kinerja yang baik agar dapat memperoleh manfaat dari portofolio yang dikelolanya (Cakrie, 2013). Di Indonesia perusahaan investasi terdiri dari kepemilikan nasional dan asing. Penelitian yang dilakukan Shukla dan Inwegen (1995) yang membandingkan kinerja reksadana saham manajer investasi lokal di pasar AS versus manajer investasi UK yang juga berinvestasi di pasar AS selama periode 1981-1993 yang menunjukkan bahwa kinerja manajer investasi UK secara signifikan berada di bawah kinerja manajer investasi AS dan juga terdapat perbedaan signifikan yang membedakan kinerja manajer investasi UK dengan kinerja manajer investasi AS.

Penelitian tersebut selanjutnya dikembangkan oleh Otten dan Bams (2007) dengan mempergunakan model Cahart sebagai pembedanya menunjukkan bahwa manajer investasi UK berinvestasi lebih banyak pada perusahaan yang lebih kecil daripada manajer investasi AS dan juga tidak terdapat perbedaan signifikan yang membedakan kinerja manajer investasi lokal dengan manajer investasi asing. Penelitian yang berbeda dilakukan oleh Galina dan Carsten (2009) yang membandingkan kinerja manajer investasi lokal di Rusia dengan kinerja manajer investasi asing yang juga berinvestasi di Rusia selama periode 2005 sampai dengan 2009. 
Direktur Pengawasan Pengelolaan Investasi Otoritas Jasa Keuangan, Fakhri Hilmi, menyatakan perusahaan investasi asing dominan disebabkan oleh pemerintah yang tidak membatasi kepemilikan asing pada industri reksadana bahkan, lewat akuisisi perusahaan asing dapat menguasai sekitar 90\% saham perusahaan investasi nasional (Wahyu dan Agustinus, 2013). Dominasi perusahaan asing juga tidak lepas dari perilaku investor Indonesia yang lebih senang berinvestasi di perusahaan asing daripada perusahaan nasional karena dianggap lebih berpengalaman melalui pengetahuan tentang industri reksadana (Fahma, 2013). Pendapat yang berbeda dikemukakan oleh Desy Tri Cakri (2013) mengenai hasil penelitiannya yang menyebutkan bahwa kinerja reksadana saham yang dikelola manajer investasi lokal ternyata lebih baik kinerjanya bila dibandingkan dengan manajer investasi asing. Adapun rumusan masalah dalam penelitian ini adalah:

1) Apakah terdapat perbedaan yang signifikan antara reksadana saham perusahaan investasi nasional dan asing di Indonesia dilihat dari kinerja dengan menggunakan metode Sharpe?

2) Manakah secara deskriptif yang lebih baik antara reksadana saham perusahaan investasi nasional dan asing di Indonesia dilihat dari market timing?

3) Manakah secara deskriptif yang lebih baik antara reksadana saham perusahaan investasi nasional dan asing di Indonesia dilihat dari stock selection? 
Investasi pada hakikatnya merupakan penempatan dana pada saat ini dengan harapan untuk memperoleh keuntungan di masa mendatang. Mudjiyono (2012) menyebutkan investasi ke dalam aktiva keuangan dapat berupa :

1) Investasi langsung yaitu investasi yang dilakukan dengan membeli dan memiliki aset keuangan secara langsung.

2) Investasi tidak langsung yaitu investasi yang dilakukan apabila pemodal membeli surat berharga yang menunjukkan kepemilikan atas suatu perusahaan investasi, dimana selanjutnya perusahaan investasi tersebut membeli sekumpulan atau portofolio atas nama pemilik perusahaan investasi tersebut. Contoh dari perusahaan investasi adalah reksadana (mutual fund) yang merupakan suatu portofolio efek yang didiversifikasikan dan dikeluarkan perusahaan investasi.

Alasan seseorang untuk melakukan investasi adalah untuk memperoleh keuntungan atau return. Return dapat berupa return realisasi yang sudah terjadi dan return ekspektasi yang belum terjadi, tetapi diharapkan terjadi di masa mendatang (expected return). Pengukuran return realisasi banyak menggunakan return total yang merupakan return keseluruhan dari suatu investasi pada suatu periode tertentu, sehingga dalam perhitungannya return ini didasarkan pada data historis. Return realisasi ini dapat digunakan sebagai salah satu pengukur kinerja perusahaan serta dapat sebagai dasar penentu return ekspektasi dan risiko pada masa yang akan datang, sedangkan return ekspektasi merupakan 
return yang diharapkan akan diperoleh investor pada masa yang akan datang. Perbedaan antara keduanya adalah return realisasi sifatnya sudah terjadi sedangkan return ekspektasi sifatnya belum terjadi (Schmid, 2010).

Risiko (risk) diartikan sebagai peluang terjadinya suatu peristiwa yang tidak diinginkan (Brigham, 2004). Fahmi (2012) dalam Mustakawarman (2016) menjelaskan risiko dapat ditafsirkan sebagai bentuk keadaan ketidakpastian tentang suatu keadaan yang akan terjadi nantinya dengan keputusan yang diambil berdasarkan berbagai pertimbangan pada saat ini. Sumber risiko dapat dibagi atas dua kelompok, yaitu risiko yang sistematis yang merupakan risiko yang mempengaruhi semua (banyak) perusahaan dan risiko tidak sistematis yang merupakan risiko yang mempengaruhi sekelompok kecil perusahaan.

Rudiyanto (2013 : 10) menyatakan bahwa reksadana sebagai wadah yang berisi uang dan instrumen efek seperti saham, obligasi, pasar uang dimana umumnya wadah tersebut ditempatkan dan diadministrasikan pada Bank Kustodian. Avramov et al (2015) menyatakan investor membeli reksadana dari sebuah perusahaan investasi pada harga per saham atau per unit penyertaan yang nilainya tergantung pada besarnya nilai aktiva bersih (NAB) per unit. NAB/unit merupakan harga beli per unit penyertaan yang harus dibeli oleh investor jika ingin berinvestasi dengan membeli unit penyertaan reksadana. NAB juga merupakan harga jual per unit penyertaan jika ingin mencairkan investasi dengan menjual unit penyertaan reksadana yang dimiliki oleh investor. NAB per unit ini 
ditentukan setiap hari dan dihitung dari nilai pasar aktiva reksadana (sekuritas, kas, dan seluruh pendapatan) dikurangi kewajiban.

Penelitian yang dilakukan oleh Evi Putri Winingrum (2011) dalam Dwimas (2013) mengenai Market Timing Ability terhadap Kinerja Reksa Dana Saham dengan menggunakan pengukuran Sharpe's menunjukkan bahwa market timing ability berpengaruh positif signifikan terhadap kinerja reksa dana. Deasy Amalia (2013) juga melakukan penelitian mengenai Market Timing terhadap Kinerja Reksadana Saham pada Reksadana Saham di Indonesia Periode Januari 2008 - Juli 2013 menunjukkan bahwa dalam Reksa Dana di Indonesia selama periode penelitian memiliki kinerja yang lebih baik dibandingkan dengan kinerja pasar sebagai pembanding nya. Sementara dari segi kemampuan market timing selama penelitian ini Manajer Investasi dari Reksa Dana di Indonesia dianggap memiliki kemampuan untuk menjual membeli saham pada waktu yang tepat (kemampuan market timing).

Penelitian yang dilakukan oleh Evi Putri Winingrum (2011) dalam Dwimas (2013) mengenai pengaruh Stock Selection Skill terhadap Kinerja Reksa Dana Saham dengan menggunakan pengukuran Sharpe's. Data yang digunakan dalam penelitian ini adalah data tahunan $\mathrm{NAB}$, risk free $\mathrm{SBI}$, expense ratio, IHSG, prospektus reksa dana dari 10 reksa dana saham periode 2006-2010. Hasil pengujian secara parsial, diperoleh hasil bahwa stock selection skill berpengaruh positif signifikan terhadap kinerja reksa dana. Kemampuan Manajer Investasi untuk melihat dalam hal stock selection yang digunakan telah dikembangkan oleh Henriksson dan Merton (1981). Sampel penelitian ini menggunakan pemenang 
Reksa Dana Award oleh majalah Investor edisi Maret 2013. Hasil penelitian ini menunjukkan bahwa dalam Reksa Dana di Indonesia selama periode penelitian memiliki kinerja yang lebih baik dibandingkan dengan kinerja pasar sebagai pembanding nya.

Galina Smirnova dan Carsten Sprenger (2009) melakukan penelitian yang membandingkan reksadana saham lokal dan internasional di Rusia selama tahun 2005 sampai 2009. Hasilnya terdapat perbedaan yang signifikan antara manajer investasi lokal dengan manajer investasi internasional di Rusia. Penelitian yang serupa dilakukan di Indonesia oleh Desy Tri Cakrie (2013) dengan dimana hasilnya terdapat 48 reksadana saham yang memiliki kinerja yang baik didominasi oleh reksadana saham yang dikelola manajer investasi lokal.

Berdasarkan paparan teori serta penelitian terdahulu dapat disusun hipotesis sebagai jawaban sementara pada penelitian ini sebagai berikut :

$\mathrm{H}_{1} \quad$ : Terdapat perbedaan kinerja signifikan antara reksadana saham perusahaan investasi nasional dan asing di Indonesia dilihat dari kinerja dengan menggunakan Indeks Sharpe.

\section{METODE PENELITIAN}

\section{Jenis dan Sumber Data}

Jenis data yang digunakan dalam penelitian ini adalah data sekunder periode 2014-2016 yang merupakan data tahunan (3 tahun) meliputi :

1) NAB (Nilai Aktiva Bersih), diperoleh dari data laporan bulanan yang dipublikasikan oleh Otoritas Jasa Keuangan melalui situs http://www.ojk.go.id 
2) SBI (Sertifikat Bank Indonesia), diperoleh dari data laporan bulanan yang dipublikasikan BI (Bank Indonesia) melalui situs http://www.bi.go.id

3) IHSG (Indeks Harga Saham Gabungan) yang diperoleh dari laporan bulanan yang dipublikasikan BEI (Bursa Efek Indonesia) melalui situs http://www.yahoofinance.com

\section{Variabel Penelitian}

Dalam penelitian ini yang menjadi variabel bebas adalah Kinerja Indeks Sharpe reksadana saham perusahaan investasi nasional (X1), Kinerja Indeks Sharpe reksadana saham perusahaan investasi asing (X2), Market timing reksadana saham perusahaan investasi nasional (X3), Market timing reksadana saham perusahaan investasi asing (X4), Stock selection reksadana saham perusahaan investasi nasional (X5) dan Stock selection reksadana saham perusahaan investasi asing (X6).

\section{Populasi dan Sampel}

Populasi pada penelitian ini yaitu seluruh reksadana saham yang terdaftar di situs http://www.ojk.go.id pada periode 2014-2016 dengan kriteria sebagai berikut:

1) Reksadana saham yang aktif dan data NAB tersedia secara lengkap selama periode penelitian yaitu 2014-2016

2) Reksadana saham yang memiliki kinerja underperform selama periode penelitian 2014-2016 yang dibandingkan dengan kinerja pasar dimana IHSG (Indeks Harga Saham Gabungan) dipergunakan sebagai patok ukurannya, 
dikeluarkan dari sampel penelitian dengan asumsi investor mengharapkan return yang lebih daripada return pasar

3) Mengkategorikan reksadana saham yang dijadikan sampel dengan mengkategorikan reksadana saham untuk perusahaan investasi nasional dan reksadana saham untuk perusahaan investasi asing sesuai dengan data kepemilikan perusahaan yang dipublikasikan melalui situs http://www.ojk.go.id.

Tabel 1.

Penentuan Jumlah Sampel Penelitian

\begin{tabular}{lcc}
\hline Kriteria & Nasional & Asing \\
\hline Jumlah perusahaan investasi reksadana & 180 & 45 \\
saham yang aktif selama periode $2014-2016$ & & 13 \\
Jumlah perusahaan investasi reksadana & 117 & \\
saham yang aktif dan data NAB tidak & & 4 \\
tersedia selama periode 2014-2016 & \multirow{2}{*}{20} & \\
Jumlah perusahaan investasi reksadana & & \\
saham yang aktif dan data NAB lengkap & & $\mathbf{2 8}$ \\
selama periode penelitian 2014-2016 tetapi & & \\
memiliki kinerja underperform & $\mathbf{4 3}$ & \\
Jumlah Sampel &
\end{tabular}

\section{Metode Pengumpulan Data}

Metode pengumpulan data dalam penelitian ini adalah data sekunder, time series dan cross section yang dilakukan dengan observasi atau pengamatan dari reksadana saham perusahaan investasi nasional dan asing selama periode penelitian 2014-2016.

\section{Teknik Analisis Data}

Metode analisis data yang digunakan dalam penelitian ini adalah analisis deskriptif kuantitatif, yang digunakan untuk menganalisis kinerja reksadana saham, market timing dan stock selection. Penguraian 
komparasi reksadana saham perusahaan investasi nasional dan asing di Indonesia disampaikan secara deskriptif serta dilengkapi dengan uji beda dua rata - rata untuk perbandingan kinerja reksadana saham perusahaan investasi nasional dan asing.

\section{HASIL DAN PEMBAHASAN}

\section{Deskripsi Reksadana Saham Perusahaan Investasi Nasional dan Asing}

\section{di Indonesia}

Berdasarkan hasil pengolahan data reksadana saham perusahaan investasi nasional dan asing di Indonesia selama periode penelitian 2014 2016 diperoleh seperti pada Tabel 2. dan Tabel 3. dibawah ini.

\section{Tabel 2.}

Daftar Reksadana Saham

Perusahaan Investasi Nasional di Indonesia

Periode 2014-2016

\begin{tabular}{rlr}
\hline No & \multicolumn{1}{c}{ Nama Produk RDS } & $\begin{array}{c}\text { Kepemilikan } \\
\text { Perusahaan Inv }\end{array}$ \\
\hline 1 & Reksa Dana Asanusa Enhanced Strategy Fund & Nasional \\
2 & Avrist Equity - Cross Sectoral & Nasional \\
3 & Batavia Dana Saham Optimal & Nasional \\
4 & Batavia Dana Saham & Nasional \\
5 & Rencana Cerdas & Nasional \\
6 & Corfina Grow-2-Prosper Rotasi Strategis & Nasional \\
7 & Jisawi Progresif & Nasional \\
8 & Reksa Dana Danareksa Mawar Rotasi Sektor & Nasional \\
9 & Danareksa Mawar & Nasional \\
10 & Reksa Dana Danareksa Mawar Konsumer 10 & Nasional \\
11 & Reksa Dana Danareksa Mawar Komoditas 10 & Nasional \\
12 & Reksa Dana Emco Mantap & Nasional
\end{tabular}


22 Mandiri Investasi Cerdas Bangsa

Nasional

23 Manulife Dana Saham

Nasional

24 Manulife Institutional Equity Fund

Nasional

25 Manulife Saham Andalan

Nasional

26 Reksadana Millenium Dynamic Equity Fund

Nasional

27 Millenium Equity Growth Fund

Nasional

28 Reksa Dana Millenium Equity

Nasional

29 Narada Saham Indonesia

Nasional

30 PNM Saham Agresif

Nasional

31 Panin Dana Maksima

Nasional

32 Reksa Dana Pratama Equity

Nasional

33 Pratama Saham

Nasional

34 Reksadana Dana Pratama Ekuitas

Nasional

35 Prospera Bijak

Nasional

36 RHB Alpha Sector Rotation

Nasional

37 RHB Prime Equity Fund

Nasional

38 SAM Indonesian Equity Fund

Nasional

39 Reksa Dana Simas Saham Unggulan

Nasional

40 Reksa Dana Simas Danamas Saham

Nasional

41 Sucorinvest Equity Fund

Nasional 


\begin{tabular}{lll}
42 & Syailendra Eqity Alpha Fund & Nasional \\
43 & Syailendra Equity Opportunity Fund & Nasional \\
\hline Sumber: Data diolah, 2017 &
\end{tabular}

Tabel 3.

Daftar Reksadana Saham Perusahaan Investasi Asing di Indonesia Periode 2014-2016

\begin{tabular}{|c|c|c|}
\hline No & Nama Produk RDS & $\begin{array}{c}\text { Kepemilikan Perusahaan } \\
\text { Investasi }\end{array}$ \\
\hline 1 & Reksa Dana AXA Maestrosaham & Asing \\
\hline 2 & Reksa Dana AXA Citradinamis & Asing \\
\hline 3 & Ashmore Dana Ekuitas Nusantara & Asing \\
\hline 4 & Ashmore Dana Progresif Nusantara & Asing \\
\hline 5 & Reksa Dana BNP Paribas Insfrastruktur Plus & Asing \\
\hline 6 & BNP Paribas Inspira & Asing \\
\hline 7 & BNP Paribas Ekuitas & Asing \\
\hline 8 & BNP Paribas Pesona & Asing \\
\hline 9 & BNP Paribas Star & Asing \\
\hline 10 & Reksa Dana BNP Paribas Solaris & Asing \\
\hline 11 & Reksa Dana Ekuitas Andalan & Asing \\
\hline 12 & Reksa Dana Bahan Trailblazer Fund & Asing \\
\hline 13 & Reksa Dana Dana Ekuitas Prima & Asing \\
\hline 14 & $\begin{array}{l}\text { Bahana Dana Prima } \\
\text { Reksa Dana CIMB-Principal Indo Equity }\end{array}$ & Asing \\
\hline 15 & Fund & Asing \\
\hline 16 & Reksa Dana First State Indoequity Peka Fund & Asing \\
\hline 17 & First State Indoequity High Conviction Fund & Asing \\
\hline 18 & First State Indoequity Value Select Fund & Asing \\
\hline 19 & FS Indoequity Dividend Yield Fund & Asing \\
\hline 20 & First State Indoequity Sectoral Fund & Asing \\
\hline 21 & Maybank Dana Ekuitas & Asing \\
\hline 22 & Nikko Indonesia Equity Fund & Asing \\
\hline 23 & Reksa Dana Schroder Indo Equity Fund & Asing \\
\hline 24 & Schroder Dana Prestasi Dinamis & Asing \\
\hline 25 & Reksa Dana Schroder 90 Plus Equity Fund & Asing \\
\hline 26 & Reksa Dana Schroder Dana Istimewa & Asing \\
\hline 27 & Schroder Dana Prestasi Plus & Asing \\
\hline 28 & Reksa Dana Schroder Prestasi & Asing \\
\hline
\end{tabular}


Berdasarkan Tabel 2. diperoleh 43 (empat puluh tiga) reksadana saham perusahaan investasi nasional selama periode penelitian yang memiliki kinerja outperform sedangkan berdasarkan Tabel 3. diperoleh 28 (dua puluh delapan) reksadana saham perusahaan investasi asing selama periode penelitan yang memiliki kinerja outperform.

Deskripsi Reksadana Saham Perusahaan Investasi Nasional di Indonesia Dilihat dari Kinerja dengan Menggunakan Indeks Sharpe

Deskripsi hasil reksadana saham perusahaan investasi nasional di Indonesia dilihat dari kinerja dengan menggunakan Indeks Sharpe selama periode penelitian 2014 - 2016 seperti tercantum pada Tabel 4. sebagai berikut :

Tabel 4. Kinerja Sharpe Reksadana Saham Perusahaan Investasi Nasional Tahun 2014-2016

\begin{tabular}{cr}
\hline Tahun & Kinerja Indeks Sharpe \\
\hline 2014 & $-1,997$ \\
2015 & $-1,581$ \\
2016 & $-1,482$ \\
\hline \multicolumn{2}{l}{ Sumber : Data diolah, 2017}
\end{tabular}

Berdasarkan Tabel 4. kinerja Indeks Sharpe yang memiliki nilai negatif selama periode penelitian disebabkan oleh rata - rata return yang diperoleh dari masing - masing produk reksadana saham perusahaan investasi nasional jauh lebih kecil daripada rata - rata return investasi bebas risiko.

Deskripsi Reksadana Saham Perusahaan Investasi Asing di Indonesia Dilihat dari Kinerja dengan Menggunakan Kinerja Sharpe 
Deskripsi hasil reksadana saham perusahaan investasi asing di Indonesia dilihat dari kinerja dengan menggunakan kinerja Sharpe selama periode penelitian 2014 - 2016 seperti tercantum pada Tabel 5. sebagai berikut :

\section{Tabel 5.}

Kinerja Sharpe Reksadana Saham

Perusahaan Investasi Asing

Periode 2014-2016

\begin{tabular}{|c|c|}
\hline Tahun & Kinerja Indeks Sharpe \\
\hline 2014 & $-2,340$ \\
\hline 2015 & $-1,619$ \\
\hline 2016 & $-1,498$ \\
\hline
\end{tabular}

Berdasarkan Tabel 5. nilai kinerja Indeks Sharpe yang negatif untuk seluruh reksadana saham selama periode penelitian dipengaruhi oleh pergerakan IHSG yang melemah.

\section{Deskripsi Reksadana Saham Perusahaan Investasi Nasional di}

\section{Indonesia Dilihat dari Market Timing}

Deskripsi hasil reksadana saham perusahaan investasi nasional di Indonesia dilihat dari Market Timing selama periode penelitian 2014 2016 seperti tercantum pada Tabel 6. sebagai berikut :

Tabel 6.

Market Timing Reksadana Saham

Perusahaan Investasi Nasional

Periode 2014 - 2016

\begin{tabular}{cr}
\hline Tahun & Market Timing \\
\hline 2014 & 8,671 \\
2015 & 5,211 \\
2016 & $-0,997$ \\
\hline \multicolumn{2}{l}{ Sumber : Data diolah, 2017}
\end{tabular}


Berdasarkan Tabel 6. terjadi penurunan nilai rata - rata market timing reksadana saham perusahaan investasi nasional selama periode penelitian yang berarti kurangnya kemampuan manajer investasi pada perusahaan investasi nasional untuk memanfaatkan waktu untuk mengoptimalkan tingkat pengembalian investor.

\section{Deskripsi Reksadana Saham Perusahaan Investasi Asing di Indonesia} Dilihat dari Market Timing

Deskripsi hasil reksadana saham perusahaan investasi asing di Indonesia dilihat dari Market Timing selama periode penelitian 2014 2016 seperti tercantum pada Tabel 7. sebagai berikut :

Tabel 7.

Market Timing Reksadana Saham Perusahaan Investasi Asing Periode 2014-2016

\begin{tabular}{cr}
\hline Tahun & Market Timing \\
\hline 2014 & 1,612 \\
2015 & 2,670 \\
2016 & $-10,716$ \\
\hline Sumber: Data diolah, 2017 &
\end{tabular}

Berdasarkan Tabel 7. berarti pada tahun 2016 reksadana saham perusahaan investasi asing tidak dapat menghasilkan return yang optimal dilihat dari nilai market timingnya yang negatif. Benny (2016) menyatakan bahwa hanya sekitar $30 \%$ produk reksadana saham di Indonesia yang mampu menerapkan market timing dengan baik sehingga kemampuan market timing reksadana saham di Indonesia masih rendah. Cuthbertson et 
al (2010) juga menyatakan hanya sebagian kecil dari manajer investasi yang mampu menempatkan diri pada market timing yang tepat.

\section{Deskripsi Reksadana Saham Perusahaan Investasi Nasional di}

\section{Indonesia Dilihat dari Stock Selection}

Deskripsi hasil reksadana saham perusahaan investasi nasional di Indonesia dilihat dari Stock Selection selama periode penelitian 2014 - 2016 seperti tercantum pada Tabel 8. sebagai berikut :

\begin{tabular}{|c|c|}
\hline \multicolumn{2}{|c|}{$\begin{array}{c}\text { Tabel } 8 . \\
\text { Stock Selection Reksadana Saham } \\
\text { Perusahaan Investasi Nasional } \\
\text { Periode 2014-2016 }\end{array}$} \\
\hline Tahun & Stock Selection \\
\hline 2014 & 0,054 \\
\hline 2015 & 0,042 \\
\hline 2016 & $-0,013$ \\
\hline
\end{tabular}

Stock selection dilakukan untuk memberikan hasil yang optimal dengan melakukan diversifikasi untuk mengendalikan risiko sehingga pada tahun 2016 reksadana saham perusahaan investasi nasional tidak dapat melakukan diversifikasi dengan baik yang terindikasi dari nilainya yang negatif.

Deskripsi Reksadana Saham Perusahaan Investasi Asing di Indonesia Dilihat dari Stock Selection

Deskripsi hasil reksadana saham perusahaan investasi asing di Indonesia dilihat dari Stock Selection selama periode penelitian 2014 - 2016 seperti tercantum pada Tabel 9. sebagai berikut : 
Tabel 9.

Stock Selection Reksadana Saham

Perusahaan Investasi Asing

Periode 2014 - 2016

\begin{tabular}{cr}
\hline Tahun & Stock Selection \\
\hline 2014 & 0,019 \\
2015 & 0,029 \\
2016 & $-0,139$ \\
\hline Sumber : Data diolah, 2017 &
\end{tabular}

Berdasarkan Tabel 9. berarti pada tahun 2016 reksadana saham perusahaan investasi asing tidak dapat menghasilkan return yang optimal dilihat dari nilai stock selectionnya yang negatif.

Komparasi Reksadana Saham Perusahaan Investasi Nasional dan Asing di

\section{Indonesia Dilihat dari Kinerja}

Komparasi reksadana saham perusahaan investasi nasional dan asing di Indonesia dilihat dari kinerja selama periode penelitian 2014 2016 ditunjukkan pada Tabel 10. sebagai berikut :

Tabel 10.

\begin{tabular}{|c|c|c|}
\hline \multicolumn{3}{|c|}{$\begin{array}{l}\text { Kinerja Sharpe Reksadana Saham } \\
\text { Perusahaan Investasi Nasional dan Asing } \\
\text { Periode 2014-2016 } \\
\end{array}$} \\
\hline & \multicolumn{2}{|c|}{ Kinerja Sharpe } \\
\hline Tahun & Nasional & Asing \\
\hline 2014 & $-1,997$ & $-2,340$ \\
\hline 2015 & $-1,581$ & $-1,691$ \\
\hline 2016 & $-1,482$ & $-1,498$ \\
\hline
\end{tabular}

Berdasarkan Tabel 10. hasil perhitungan kinerja Sharpe reksadana saham perusahaan investasi nasional lebih tinggi daripada kinerja Sharpe reksadana saham perusahaan investasi asing di Indonesia selama periode 
penelitian 2014-2016 sedangkan untuk hasil uji beda disajikan pada Tabel 11. yaitu :

Tabel 11.

Uji Beda Kinerja Sharpe Reksadana Saham 2014-2016

\begin{tabular}{lccc}
\hline \multicolumn{1}{c}{ Reksadana Saham } & Mean & Beda & $\begin{array}{c}\text { Sig }(2 \\
\text { tailed })\end{array}$ \\
\hline $\begin{array}{l}\text { Perusahaan Investasi } \\
\text { Nasional }\end{array}$ & $-1,686$ & $-0,132$ & 0,688 \\
Perusahaan Investasi Asing & $-1,819$ & & \\
\hline \multicolumn{2}{l}{ Sumber : Data diolah, 2017} & &
\end{tabular}

Berdasarkan Tabel 11. dapat dilihat nilai mean kinerja Sharpe reksadana saham perusahaan investasi nasional sebesar $-1,686$ dan nilai mean reksadana saham perusahaan investasi asing sebesar $-1,819$ sehingga dapat dikatakan kinerja Sharpe reksadana saham perusahaan investasi nasional lebih tinggi daripada kinerja Sharpe reksadana saham perusahaan investasi asing di Indonesia selama periode penelitian 2014-2016. Jika dilihat dari nilai signifikansinya sebesar 0,688 yang lebih besar dari $p$ value $=0,05$ menunjukkan bahwa tidak terdapat perbedaan signifikan antara kinerja Sharpe reksadana saham perusahaan investasi nasional dan asing di Indonesia selama periode penelitian 2014-2016.

Hasil penelitian ini mendukung hasil penelitian sebelumnya yaitu Baskara (2015) serta Otten dan Bams (2007) yang menyatakan bahwa tidak terdapat perbedaan yang signifikan antara kinerja manajer investasi lokal dan asing. Jordan (2014) menjelaskan tidak terdapatnya perbedaan yang signifikan antara kinerja perusahaan investasi nasional dan asing disebabkan oleh investor yang cenderung melihat return yang dihasilkan 
oleh reksadana saham tersebut daripada melihat perusahaan investasinya karena yang paling penting adalah manajer investasi yang timnya kompeten dan solid sehingga menciptakan reliabilitas serta kepercayaan dari investor.

\subsubsection{Komparasi Reksadana Saham Perusahaan Investasi Nasional dan Asing di Indonesia Dilihat dari Market Timing}

Komparasi reksadana saham perusahaan investasi nasional dan asing di Indonesia dilihat dari market timing selama periode penelitian 2014 - 2016 ditunjukkan pada Tabel 12. sebagai berikut :

\section{Tabel 12.}

Market Timing Reksadana Saham Perusahaan Investasi Nasional dan Asing Periode 2014-2016

\begin{tabular}{ccr}
\hline \multicolumn{3}{c}{ Market Timing } \\
Tahun & Nasional & \multicolumn{1}{c}{ Asing } \\
\hline 2014 & 8,671 & 1,612 \\
2015 & 5,211 & 2,670 \\
2016 & $-0,997$ & $-10,716$ \\
\hline Sumber : data diolah, 2017 &
\end{tabular}

Berdasarkan Tabel 12. hasil perhitungan market timing reksadana saham perusahaan investasi nasional lebih baik daripada market timing reksadana saham perusahaan investasi asing di Indonesia selama periode penelitian 2014-2016. Tahun 2016 market timing untuk reksadana saham perusahaan investasi nasional dan asing bernilai negatif yang berarti tidak tepatnya timing yang dilakukan pada saat membeli dan menjual. Penyebab dari negatifnya nilai market timing tahun 2016 adalah situasi kondisi politik 
dan ekonomi Indonesia yang tidak stabil serta dampak pemulihan ekonomi global.

\section{Komparasi Reksadana Saham Perusahaan Investasi Nasional dan} Asing di Indonesia Dilihat dari Stock Selection

Komparasi reksadana saham perusahaan investasi nasional dan asing di Indonesia dilihat dari stock selection selama periode penelitian 2014 - 2016 ditunjukkan pada Tabel 13. sebagai berikut:

Tabel 13.

Stock Selection Reksadana Saham Perusahaan Investasi Nasional dan Asing Periode 2014-2016

\begin{tabular}{ccr}
\hline & \multicolumn{2}{c}{ Stock Selection } \\
Tahun & Nasional & \multicolumn{1}{c}{ Asing } \\
\hline 2014 & 0,054 & 0,019 \\
2015 & 0,042 & 0,029 \\
2016 & $-0,013$ & $-0,139$ \\
\hline Sumber : data diolah, 2017 &
\end{tabular}

Berdasarkan Tabel 13. hasil perhitungan stock selection reksadana saham perusahaan investasi nasional lebih tinggi daripada stock selection reksadana saham perusahaan investasi asing di Indonesia selama periode penelitian 2014-2016. Tahun 2016 stock selection untuk reksadana saham perusahaan investasi nasional dan asing bernilai negatif yang berarti tidak tepatnya seleksi saham yang dilakukan. Penyebab dari negatifnya nilai stock selection tahun 2016 adalah situasi kondisi politik dan ekonomi Indonesia yang tidak stabil serta dampak pemulihan ekonomi global.

\section{SIMPULAN DAN SARAN}


Berdasarkan hasil penelitian dan pembahasan maka dapat diperoleh simpulan sebagai berikut :

1). Komparasi reksadana saham perusahaan investasi nasional dan asing di Indonesia dilihat dari kinerja Sharpe selama periode penelitian 2014 - 2015 menunjukkan tidak terdapat perbedaan yang signifikan antara kinerja reksadana saham perusahaan investasi nasional dan kinerja reksadana saham perusahaan investasi asing di Indonesia selama periode penelitian 2014-2016 karena tingkat return yang dihasilkan masing - masing reksadana saham lebih kecil daripada tingkat return investasi bebas risiko sehingga investor lebih memilih untuk berinvestasi pada investasi bebas risiko seperti SBI (Sertifikat Bank Indonesia).

2). Komparasi reksadana saham perusahaan investasi nasional dan asing di Indonesia dilihat dari market timing selama periode penelitian 2014 - 2016 menunjukkan market timing reksadana saham perusahaan investasi nasional lebih baik daripada market timing reksadana saham perusahaan investasi asing di Indonesia selama periode penelitian 2014 - 2016 karena manajer investasi pada perusahaan investasi nasional memiliki informasi yang lebih lengkap sehingga dapat mengambil keputusan untuk melakukan timing jual maupun beli dengan tepat daripada manajer investasi pada perusahaan investasi asing.

3). Komparasi reksadana saham perusahaan investasi nasional dan asing di Indonesia dilihat dari stock selection selama periode penelitian 2014 - 2016 menunjukkan stock selection reksadana saham perusahaan investasi nasional lebih baik daripada stock selection reksadana saham perusahaan investasi 
asing di Indonesia selama periode penelitian 2014 - 2016 karena manajer investasi pada perusahaan investasi nasional memiliki informasi yang lebih lengkap sehingga dapat mengambil keputusan untuk melakukan pemilihan saham dengan tepat yang akan dimasukkan dan dikeluarkan pada reksadana saham daripada manajer investasi pada perusahaan investasi asing.

Berdasarkan simpulan yang dikemukakan maka dapat disusun saran - saran sebagai berikut :

1). Bagi investor penelitian ini menunjukkan bahwa jika dilihat dari kinerja, market timing dan stock selection perlu dipertimbangkan untuk memilih berinvestasi pada reksadana saham yang dapat memberikan tingkat pengembalian yang optimal dengan tingkat risiko yang dapat ditoleransi bukan berdasarkan perusahaan investasi nasional atau perusahaan investasi asing.

2). Bagi perusahaan investasi penelitian ini menunjukkan bahwa perlu dilakukan perbaikan dalam hal kinerja, market timing dan stock selection sehingga dapat menghasilkan tingkat pengembalian yang lebih baik serta dapat mewaspadai risiko yang mungkin terjadi dari investasi.

3). Penelitian ini hanya mengambil sampel reksadana saham outperform yang menyampaikan laporan kepada OJK (Otoritas Jasa Keuangan) secara lengkap selama periode penelitian 2014 - 2016 sehingga untuk penelitian selanjutnya pengambilan sampel reksadana saham dapat dilakukan melalui kontan (situs online yang memuat informasi tentang reksadana saham terbaik) serta perbandingan reksadana saham perusahaan investasi nasional dan asing tidak 
hanya dilihat dari kinerja Sharpe, market timing dan stock selection tetapi juga dapat dilihat dari biaya transaksi atau fund size reksadana saham.

4). Perbandingan yang dilakukan pada penelitian ini hanya terbatas kepada reksadana saham perusahaan investasi nasional dan asing sehingga untuk penelitian yang selanjutnya disarankan untuk melakukan perbandingan pada jenis reksadana yang lain seperti reksadana pasar uang, reksadana pendapatan tetap atau reksadana campuran.

\section{IMPLIKASI PENELITIAN}

Hasil penelitian ini dapat memberikan informasi dalam mengambil keputusan investasi yang tidak berbeda secara signifikan hasilnya antara reksadana saham berdasarkan kepemilikan perusahaan investasi nasional dan asing jika dilihat dari kinerja karena return yang dihasilkan oleh reksadana saham lebih kecil dari investasi bebas risiko yang diproksikan dengan SBI (Sertifikat Bank Indonesia) sehingga investor lebih memilih berinvestasi pada instrumen bebas risiko karena tingkat pengembaliannya lebih baik.

Jika dilihat dari market timing dan stock selection selama periode penelitian investor dapat lebih memilih reksadana saham perusahaan investasi nasional daripada asing karena memiliki informasi yang lebih lengkap serta pengalaman tentang perubahan kondisi politik dan ekonomi di Indonesia sehingga analisa dan keputusan investasi yang dilakukan lebih baik. 


\section{REFERENSI}

Avramov, Doron, Si Cheng \& Allaudeen Hameed. 2015. Mispriced Stocks and Mutual Fund Performance, Paper, The Hebrew University of Jerusalem

Baskara, G. 2015. Analisis Kinerja Reksadana Saham berdasarkan Manajer Investasi Asing dan Lokal pada Saat Krisis dan Pasca Krisis Subrime Mortgage, Tesis, Program Magister Manajemen UGM tidak dipublikasikan

Benny, M. 2013. Analysis of Mutual Fund's Performance and Persistence in Indonesia, International Journal of Science and Research, Vol. 4, pp. $1404-1408$

Bernadiaz, D,. dan Hidayati, Lina . 2015. Analisis Pengukuran Kinerja Reksadana Saham Menggunakan Metode Sharpe, Metode Treynor dan Metode Jensen (Studi pada Reksadana Periode 2012 -2014), EJurnal Manajemen Bisnis Indonesia, Vol. 4, Edisi 5, Universitas Negeri Yogyakarta

Brigham, Eugene F dan Joel F. Houston. 2006. Dasar-Dasar Manajemen Keuangan. Salemba Empat. Jakarta

Cakrie, D. 2013. Perbandingan Kinerja Investasi pada Reksadana Saham yang Dikelola Manajer Investasi Lokal dan Asing di Indonesia, Tesis, Program Magister Manajemen UGM tidak dipublikasikan

Deasy, A,. dan Sihombing,P. 2013. Analisis Kemampuan Stock Selection dan Market Timing pada Reksadana Saham di Indonesia Periode $\begin{array}{lllll}\text { Januari } & 2008 & - & \text { Juli } & 2013 .\end{array}$ (online),(http://adlermanurungpress.com/journal/datajournal)

Dwi Mas, Sukma A,. 2013.Pengaruh Kebijakan Alokasi Aset,Kinerja Manajer Investasi dan Ukuran Reksadana terhadap Kinerja Reksadana Saham di Indonesia, E-Jurnal Akuntansi UNUD, pp 250265

Fama, E.F. 1972. Component of Investment Performance. Journal of Finance Vol. 27 (June): 551-68

Fahma, Resi. 2013. Membuat Investor Lokal Menikmati Manisnya Reksadana, Fortune Indonesia Vol. $62 \mathrm{Mei}$

Galina, S., and Carsten S. 2009. Do Local Perform Better than Foreigners : Evidence From Mutual Funds Investing in Rusia, (online), (https: //www.researchgate.net/publication/265228342)

Gopalakrishnan, M. Muthu. 2014. Optimal Portofolio Selection using Sharpe's Index Model. Indian Journal of Applied Research, Vol. 4, Issue 1 
Hanggoro, W. 2014. Analisis Pengukuran Kinerja Reksadana Saham yang Tercatat pada Bursa Efek Indonesia dengan Metode Sharpe, Treynor dan Jensen, E-Jurnal Manajemen Bisnis Indonesia, Vol. 3, Edisi 6, Universitas Negeri Yogyakarta

Kalpesh, P., and Mahesh, P. 2012. Comparative Study on Performance Evaluation of Mutual Fund Schemes of Indian Companies, Journal Arts, Science \& Commerce, Vol. 3, pp 47-59

Keith Cuthbertson and Dirk Nitzsche.2012.Performance, Stock Selection and Market Timing of the German Equity Mutual Fund Industry, Paper, European Financial Management Association

Mudjiyono. 2012. Investasi dalam Saham \& Obligasi dan Meminimalkan Risiko Sekuritas pada Pasar Modal Indonesia, Jurnal STIE Semarang, Vol.4, No. 2, pp. 1-18

Mustakawarman. 2016. Kinerja Portofolio Saham Undervalued dan Kinerja Portofolio Saham Overvalued pada Indeks LQ 45 di Bursa Efek Indonesia, Tesis, Program Pascasarjana UNUD tidak dipublikasikan

Narend, S,. and Thenmozhi.2014. Performance of ETFs and Index Fund : A Comparative Analysis, Research Project Paper, Departement of Management Studies Indian Institute of Technology, Madras

Nurjanah, N. 2016. Analisis Pengukuran Kinerja Reksadana Saham dengan Metode Sharpe, Jensen, Treynor, $\mathbf{M}^{2}$, dan Information Ratio di Bursa Efek Indonesia, Jurnal Management Bisnis Indonesia, Vol. 5,No.6, Universitas Negeri Yogyakarta

Otoritas Jasa Keuangan. 2014. Peraturan Otoritas Jasa Keuangan Nomor 25/POJK.04/2014 tentang Perizinan Wakil Manajer Investasi. Ketua Dewan Komisioner Otoritas Jasa Keuangan.Jakarta

Rudiyanto. 2016. Seri Panduan Investasi Reksa Dana untuk Pemula. PT. Elex Media Komputindo. Jakarta

Shilpi,Pal,.and Arti, Chandani.2014. A Critical Analysis of Selected Mutual Funds in India,Procedia Economics and Finance, Vo. 11, pp 481-494

Sung Sin Kim., and Pando, Sohn. 2013. Market Timing Performance in Korean Fund Market : Evidence from Portofolio Holdings, Procedia Economics and Finance, Vol. 5, pp 443-452

Wahyu dan Agustinus. 2013. MI Asing Menguasai 59\% Aset Reksadana, (online), (http://www.kontan.co.id) 